\title{
OTIMIZAÇÃO DE PROTOCOLOS PARA A EXTRAÇÃO DE DNA GENÔMICO EM Physalis L.
}

\author{
André Pinto Lima ${ }^{1}$; Adriana Rodrigues Passos ${ }^{2}$; Hortência Kardec da Silva ${ }^{3}$; \\ Rafael Cruz Cordeiro ${ }^{4}$ \\ 1.Bolsista, PROBIC/UEFS, Graduando em Agronomia, Universidade Estadual de Feira de Santana, \\ e-mail: andre8fs@hotmail.com \\ 2. Professora Adjunta, Orientadora, Departamento de Ciências Biológicas, Universidade Estadual de Feira de \\ Santana e-mail: adrianarpassos@yahoo.com.br \\ 3. Mestre em Recurso Genético Vegetal, Co-orientadora, Departamento de Ciências Biológicas, Universidade \\ Estadual de Feira de Santana, e-mail: hortenciakardec@hotmail.com \\ 4. Participante do projeto, Departamento de Ciências Biológicas, Universidade Estadual de Feira de Santana, \\ e-mail: rccordeiro12@gmail.com
}

PALAVRAS-CHAVE: Quantificação de DNA, Variabilidade genética, Biotecnologia.

\section{INTRODUÇÃO}

O gênero Physalis L., pertence à família das solanáceas, e corresponde a um grupo com espécies economicamente importantes como o tomate (Lycopersicon esculentum Mill.) e a batata (Solanum tuberosum L.). As espécies, pertencentes ao gênero, são importantes porque fornecem frutos comestíveis e uma grande diversidade de bioprodutos, que têm um amplo espectro de atividades biológicas. Diante da importância da cultura tornam-se necessários estudos moleculares para analisar a diversidade genética, pois a quantificação da variabilidade genética auxilia no planejamento de estratégias mais eficazes que venham a maximizar a utilização dos recursos genéticos com vista a sua conservação (SILVA, 2014).

No entanto, estudos moleculares dependem diretamente da qualidade do DNA extraído, portanto a otimização e estabelecimento de protocolos de extração são necessários visto que, um bom procedimento de extração deve produzir DNA de qualidade e quantidades adequadas para manipulação (ROMANO, 1998). As técnicas de quantificação fornecem informações importantes, tendo em vista que podem revelar a qualidade da amostra de DNA, isenta ou não de contaminação por proteínas. A otimização de protocolos de extração de DNA para caracterização genética é um passo necessário no campo da biologia molecular. Segundo Chiari et al. (2009), os métodos convencionais de extração de DNA são executáveis em todas as espécies, sendo necessário adaptações e modificações de acordo com o organismo trabalhado. Os ajustes de protocolo são feitos para que a extração de DNA seja simples, rápida e de baixo custo e obtenham-se DNA de qualidade para análises moleculares (DANNER et al., 2011). A extração de DNA é a primeira etapa para a utilização de genomas em diferentes técnicas da genética molecular, e a sua pureza e qualidade são sempre os prérequisitos principais (ARBI et al., 2010).

Assim, o trabalho proposto tem por objetivo testar protocolos de extração de DNA e estabelecer o que apresente uma maior quantidade e qualidade de DNA genômico de Physalis, para fins de análise de divergência genética via marcadores moleculares.

\section{MATERIAL E MÉTODOS}

O experimento foi conduzido no Laboratório de Genética Molecular (LAGEM) da Unidade Experimental Horto Florestal, pertencente à Universidade Estadual de Feira de Santana (UEFS). As sementes de fisalis foram semeadas em casa de vegetação e transplantadas com aproximadamente 40 dias para campo com adubação adequada. Para a extração do DNA, folhas jovens foram coletadas, desinfetadas em solução de hipoclorito de sódio a 2\%. Foram testados dois protocolos de extração de DNA. 
Teste de Protocolos e Métodos de Extração - Foram testados dois protocolos para extração de DNA, o proposto por Doyle e Doyle (1990) e Santos (2017), em vias de publicação. Foram testados métodos de maceração com nitrogênio líquido, maceração direta no tampão de extração e maceração em areia na presença do tampão de extração. Ainda, serão realizados testes a fim de determinar a melhor forma de armazenamento do material vegetal, sendo utilizadas amostras do material vegetal fresco, armazenado em freezer e em sílica gel.

Protocolo 1. Doyle e Doyle (1990) - Cerca de $300 \mathrm{mg}$ de tecido foliar fresco foram pulverizados em cadinhos de porcelana com nitrogênio líquido e transferidos para tubos de microcentrífuga de $2 \mathrm{~mL}$. Foram adicionados ao material $800 \mu \mathrm{L}$ de tampão de extração (2\% CTAB; 1,3 M NaCl; 0,2\% 2- $\beta$-mercaptoetanol; 20 mM EDTA; $100 \mathrm{mM}$ Tris- $\mathrm{HCl} \mathrm{pH} 8 ; 1 \%$ PVP 40). Incubou-se a $70^{\circ} \mathrm{C}$ por 60 minutos, invertendo os tubos, suavemente, a cada 10 minutos. Após deixar esfriar à temperatura ambiente por 5 minutos, foi realizada a desproteinização, adicionando-se $700 \mu \mathrm{L}$ de clorofórmio-álcool isoamílico. Em seguida, as amostras foram agitadas, por suaves inversões, por 10 minutos e centrifugadas a $4^{\circ} \mathrm{C}$, a $18,845 \mathrm{~g}$, por 10 minutos. O sobrenadante de cada amostra foi transferido para tubos de $2 \mathrm{~mL}$, foram adicionados $55 \mu \mathrm{L}$ de CTAB $2 \%$, e o processo de desproteinização foi repetido, acrescentando-se o mesmo volume de clorofórmio-álcool isoamílico. Para a precipitação do DNA, foram adicionados ao sobrenadante $700 \mu \mathrm{L}$ de isopropanol gelado. Os tubos foram mantidos a $-20^{\circ} \mathrm{C}$ por duas horas e, a seguir, centrifugados como anteriormente. O sobrenadante foi descartado e o precipitado foi lavado duas vezes com etanol $70 \%$ e seco em temperatura ambiente, por aproximadamente 60 minutos. Posteriormente, os ácidos nucleicos totais foram ressuspendidos em $150 \mu \mathrm{L}$ de água contendo RNAse na concentração de $40 \mu \mathrm{g} / \mathrm{mL}$ e colocados em banho-maria, a $37^{\circ} \mathrm{C}$ por 60 minutos, para a completa ressuspensão do DNA e digestão do RNA. Após esse período, o DNA foi novamente precipitado, centrifugado e ressuspendido em $150 \mu \mathrm{L}$ de água como já descrito. A conservação do DNA extraído foi feita a $-20^{\circ} \mathrm{C}$.

Protocolo 2. Santos et al (2017, no prelo) - Cerca de 0,3 gramas foram macerados de tecido vegetal com $3 \mathrm{ml}$ de tampão de extração (CTAB 10\%; $\mathrm{NaCl} 5 \mathrm{M}$; Tris- $\mathrm{HCl} \mathrm{1M}$ pH 8,0; EDTA 0,5M; Na Sulfite, PVP (Polivinilpirrolidona) e água mili-Q - mantido a $65^{\circ} \mathrm{C}$ ) em um saco plástico. Assim transferidos $2 \mathrm{ml}$ do macerado para tubos de $2 \mathrm{ml}$, sendo misturados por inversão e incubados por 30 minutos em banho-maria a $65^{\circ} \mathrm{C}$, agitando a cada 10 minutos. Ao atingir o tempo, os tubos foram centrifugados a 10000 RPM a temperatura ambiente por 5 minutos, o sobrenadante foi transferido para novos tubos de $2 \mathrm{ml}$. Foram adicionados $800 \mu \mathrm{L}$ de álcool Isoamilico e misturado por inversão. As amostras foram centrifugadas por 10 minutos a 10000 RPM a temperatura ambiente. Após coletado o sobrenadante ouve a transferência para novos tubos de 1,5 $\mathrm{ml}$. Adicionando $600 \mu \mathrm{L}$ de álcool Isopropilico (gelado), equivalente a aproximadamente a $2 / 3$ do volume coletado, sendo homogeneizado suavemente e incubado a $-20^{\circ} \mathrm{C}$ por 30 minutos. Foram centrifugados a 10000 RPM a $4^{\circ} \mathrm{C}$ por 10 minutos e o precipitado foi lavado com $500 \mu \mathrm{L}$ de etanol $70 \%$, assim deixando secar o pellet formado. O DNA isolado foi ressuspendido em $30 \mu \mathrm{L}$ de tampão TE (Tris- $\mathrm{HCl} 10$ $\mathrm{mM}$ pH 8.0 e EDTA $1 \mathrm{mM}$ ), (RNAse $-1 \mu \mathrm{L}$ amostra) e as amostras foram colocadas na estufa a $37^{\circ} \mathrm{C}$ para a completa solubilização de DNA, por 30 minutos. O DNA concentrado foi conservado a $-20^{\circ} \mathrm{C}$.

Avaliação do DNA obtido - Após a extração do material genético, foi realizada a diluição do DNA com o uso de TE gelado. Em seguida, realizou a verificação da qualidade e quantidade do DNA através de eletroforese em gel de agarose a $0,8 \%$, as amostras foram coradas com GelRed, e a eletroforeses a uma voltagem igual a $60 \mathrm{~W}$ por 1hora. As amostras foram visualizadas através do sistema de fotodocumentação. A 
quantificação do DNA foi realizada por comparação com o DNA Fago lambda de concentração conhecida. Após quantificação, as amostras tiveram a sua concentração ajustada para $5 \mathrm{ng} / \mu \mathrm{L}$ por diluição em tampão TE e foram verificadas, novamente, por eletroforese em gel de agarose a $1 \%$ sob as condições especificadas acima.

\section{RESULTADOS E DISCUSSÃO}

Ao visualizar o perfil eletroforético das amostras foi possível verificar que apenas um dos protocolos testados foi eficiente para isolamento de DNA de Physalis L. em quantidade adequada para estudos moleculares, tendo sido detectadas diferenças nos dois protocolos utilizados. O protocolo proposto por Doyle e Doyle (1990) se mostrou insatisfatório para a extração de DNA de Physalis L., tanto em relação à quantidade quanto à qualidade do DNA isolado, uma vez que este se apresentou totalmente danificado em todas as amostras (Figura 1).

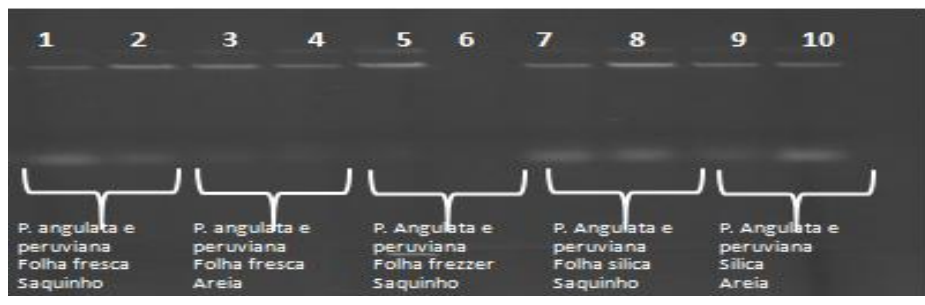

Figura 1: Analise Eletroforética do DNA genômico de Physalis L. utilizando o protocolo de Extração do DNA, Doyle e Doyle (1990). Amostras aplicadas com volume de $5 \mu \mathrm{L}$. Amostras de genótipos da Unidade Experimental Horto Florestal.

O protocolo 2 , Santos et al. (2017, no prelo), produziu DNA de boa qualidade para todas as formas de armazenamento do material vegetal testadas (material vegetal fresco, armazenado em freezer e em sílica gel ) para Physalis L., não havendo contaminação e degradação (Figura 2). Segundo Romano e Brasileiro (1999) essa boa qualidade é definida pela falta de DNA confinado no poço e de arraste vertical no gel, na devida ordem. A liberação de DNA também foi favorecida pela maceração das folhas com o tampão onde foi acrescentada uma maior quantidade em porcentagem de CTAB (tampão de extração), este protocolo decorreu de modificações nas etapas de maceração e na maior porcentagem do CTAB (tampão de extração), possibilitando a obtenção de materiais com melhor qualidade e quantidade do que foi encontrado no protocolo anterior.

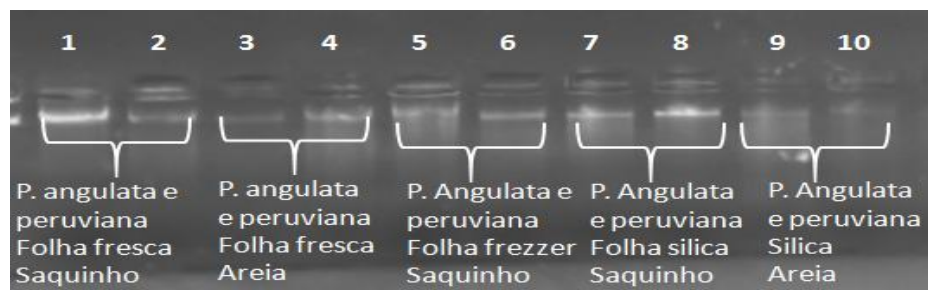

Figura 2: Analise Eletroforética do DNA genômico de Physalis L. utilizando o protocolo de Extração do DNA, Santos et al (2017, no prelo). Amostras aplicadas com volume de $5 \mu \mathrm{L}$. Amostras de genótipos da Unidade Experimental Horto Florestal.

O aumento da concentração de CTAB no tampão apresentou melhor quantidade e qualidade do DNA extraído (Figura 2). O procedimento com CTAB tem sido muito empregado para extração de tecidos frescos e diversos protocolos têm sido apresentados para esse propósito, (Machado, 1990). O tampão com o CTAB na concentração de $10 \%$ foi eficiente para a extração de DNA no protocolo 2 quando comparado com o tampão de extração de concentração de $5 \%$ de CTAB do protocolo 1. Protocolos que utilizam CTAB na extração tem o efeito de proporcionar a degradação dos ácidos nucleicos dos polissacarídeos, já que os polissacarídeos possuem dissolução especifica na presença desse detergente (ROMANO \& BRASILEIRO, 1999). 
Autores como Schmitt et al. (2014) e Ferreira et al. (2008), testaram concentrações de CTAB (2\% e 5\%) e verificaram que apenas na concentração de 5\% houve isolamento de DNA, sendo que Schmitt et al. fazendo extração de Curcuma longa (Zingeberaceae) observaram que a concentração de $2 \%$ não foi eficaz e resultado semelhante foi encontrado por Ferreira et al. (2008), que afirmam que com a utilização de CTAB a $2 \%$ não houve isolamento de DNA de buriti na extração. Segundo Silva et al. (2014) ultilizando o CTAB a 5\% a uma maior eficiência na extração de DNA de Anacardium giganteum ultilizando folhas jovens. Neste trabalho destaca-se que a concentração de CTAB de $10 \%$ obteve uma melhor eficiência no processo de extração.

Analisando a totalidade e qualidade dos DNAs extraídos, verificada pela eletroforese em gel de agarose, apresentada nas Figuras 1 e 2. Foram obtidas amostras íntegras de DNA através do protocolo 2 para as amostras analisadas, pois não se notou arraste vertical dos DNAs no gel, em grandes proporções que pudessem afetar a qualidade do material extraído.

\section{CONCLUSÕES}

O protocolo 2 foi mais eficiente na extração de DNA de folhas de Physalis L., revelando grande potencial para extrair DNA genômico de boa qualidade e quantidade. Ademais, esse protocolo apresenta custo menos elevado, sendo uma alternativa viável para uso rotineiro.

\section{REFERÊNCIAS}

ARBI, G.et al. A simple, rapid and efficient method for the extraction of genomic DNA from Allium roseum L. (Alliaceae). Afr. J. Biotechn, 2010.

CHIARI, L. Comparação de três métodos de extração de DNA genômico para análises moleculares em Stylosanthes guianensis. Circular Técnica - Embrapa. Campo Grande, MS, 2009.

CHAVES, A.C. Propagação e avaliação fenológica de Physalis sp. na região de

Pelotas-RS. 2006. Tese (Doutorado) - Universidade Federal de Pelotas, Pelotas, 2006. DANNER, M. A. et al.Proposta de protocolo para extração de DNA de jabuticabeira, Ciência Florestal, Santa Maria, 2011.

DOYLE, J.J.; DOYLE, J.L. Isolation of plant DNA from fresh tissue. Focus, 1990. FERREIRA, M. F. M.; PIMENTA, M. A. S.; JÚNIOR, A. F. M.;TISSOT, S. A.;FERREIRA, P. H. G.;VALÉRIO, H. M.;OLIVEIRA, D. A. Avaliação da eficiência de três metodologias de extração de DNA do buriti (Mauritia flexuosa Mart.) a partir de folhas e caule. In: IX Simpósio Nacional do Cerrado. Brasília, 2008. MACHADO, M. A. Isolation of DNA from Frech Tissue: Focus, 1990.

ROMANO, E.; BRASILEIRO, A. C. M. Extração de DNA de plantas. Biotecnologia, Ciência e Desenvolvimento, Brasília, 1999.

SANTOS, R. M. F. et al. A PROTOCOL FOR LARGE SCALE GENOMIC DNA ISOLATION FOR CACAO GENETICS ANALYSIS. African Journal of Biotechnology. 2014.

SILVA, B. M.; DALBOSCO, E. Z.; BOTINI, N.; FARIA, R. B.; ROSSI, A. A. B. Protocolo para extração de DNA genômico de Anacardium giganteum W. Hancock Ex. Engl. (Anacardiaceae). Enciclopédia Biosfera, Goiânia, 2014. SCHMITT, K. F. M.; SILVA, B. M.; ROSSI, A. A. B.; SANDER, N.; SILVA, C. J. Estabelecimento e otimização de protocolo para extração e amplificação de DNA em tecido foliar de Curcuma longa (L.). Enciclopédia Biosfera, Goiânia, 2014. 